\title{
ECtHR DECISIONS THAT INFLUENCED THE CRIMINAL PROCEDURE OF UKRAINE
}

\section{Oksana Kaplina and Anush Tumanyants}

Summary: 1. Introduction. - 2. The Significance of the Convention as an Instrument of the European Public Order. 3. ECHR and the Practice of the ECtHR as a Guide for the Reformation of Criminal Justice in Ukraine. - 3.1. The Principles of Criminal Proceedings: Freedom from Self-disclosure and the Right not to Testify against Close Relatives and Family Members; Immediacy of Testimonies, Objects and Documents Examination; Presumption of Innocence, Ensuring the Right to Defence and Their Implementation in the New CrPC of Ukraine 2012. - 3.2. Obligations of Ukraine Regarding the Creation of a System of Free Legal Aid. - 3.3. Positive Legislative Reaction of Ukraine to the Recommendations Made by the ECtHR Regarding the Standardisation of Measures to Ensure Criminal Proceedings and Precautionary Measures. - 3.4. Problems of Admissibility of Evidence and Ensuring the Rights of Individuals to Review the Materials of the Pre-trial Investigation. - 4. ECHR as a Living Instrument and Act of Direct Action. - 5. Reserves for the Improvement of National Legislation in the Context of Protection of Human Rights and Freedoms in Accordance with the Legal Positions of the ECtHR. - 6. Conclusions.

To cite this article: 0 Kaplina, A Tumanyants, 'ECtHR Decisions That Influenced the Criminal Procedure of Ukraine' 2021 1(9) Access to Justice in Eastern Europe 102-121. D0I: 10.33327/AJEE-18-4.1-a000048

To link to this article: https://doi.org/10.33327/AJEE-18-4.1-a000048

Submitted on 05 Dec 2020 / Revised 21 Jan 2021 / Approved 22 Feb 2021 / Published online: 01 Mar 2021 View data Submit your article to Access to Justice in Eastern Europe http://ajee-journal.com/submissions

\section{ACKNOWLEDGEMENTS}

The authors would like to express their gratitude to the reviewers for their help and to the English editor.

\section{CONFLICT OF INTEREST}

The authors have declared that no conflict of interest or competing interests exist. Prof. Oksana Kaplina serves as a Member of the Scientific Advisory Board of the Supreme Court, but despite this, she does not represent any views of this body in this particular research, nor is she bound by their views.

\section{CONTRIBUTORS}

All the co-authors read and approved the final version and agreed to be accountable for all aspects of this article. 


\title{
ECTHR DECISIONS THAT INFLUENCED THE CRIMINAL PROCEDURE OF UKRAINE
}

\author{
Kaplina Oksana \\ Dr. Sc. (Law), Prof., Head of Department of Criminal Procedure, \\ Yaroslav Mudryi National Law University, Kharkiv, Ukraine \\ Tumanyants Anush \\ PhD (Law), Assoc. professor at the Department of Criminal Procedure, \\ Yaroslav Mudryi National Law University, Kharkiv, Ukraine
}

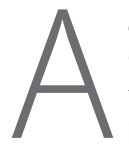

bstract As of 2020, 70 years have passed since the day of the adoption of the Convention for the Protection of Human Rights and Fundamental Freedoms (ECHR), which Ukraine ratified in September 1997. It was from this date that the countdown to significant democratic transformations in Ukraine and the establishment of human and civil rights and freedoms began. In this article, the authors raise relevant issues of reforming the criminal process of Ukraine in the context of European standards. The old Code of Criminal Procedure of Ukraine was adopted in 1960 and was in force for almost half a century. During this time, it became obsolete and bore a significant imprint of the Soviet past, which was manifest in both the bodies that conducted the trial and had primarily repressive powers and the public interests that dominated the rights and legitimate interests of those involved in criminal justice.

The conditions under which the first steps aimed at realising the importance of the Convention and the value of human rights enshrined in it took place were not easy. The path of reform processes in criminal proceedings was associated with the confrontation of the Soviet past with modern transformation. It was difficult to realise the need to harmonise national legislation with European standards of human rights and freedoms and consolidate their perception as one of the necessary conditions for Ukraine's integration into the European legal space, as well as the need for a conceptually new worldview for both the people of Ukraine and law enforcement bodies - officers, judges, and prosecutors.

The authors summarise the most important decisions of the ECtHR made on complaints against Ukraine during the period of the reform of criminal procedure legislation, analyse the problems identified by the ECtHR, and illustrate how the legislator implemented the ECtHR standards in national criminal procedure legislation. They note that on the basis of the Convention and the case-law of the ECtHR in criminal procedure legislation, important principles of criminal proceedings, such as adversarial proceedings, direct examination of evidence, the right to defence, the right not to testify against oneself and close relatives, and reasonable time are legitimised. For the first time, the legislation of Ukraine has enshrined a rule on the inadmissibility of evidence obtained as a result of a significant violation of human rights and freedoms. A separate segment of the article is devoted to the consideration of amendments to the criminal procedure legislation regarding the protection of the rights and legitimate interests of a person in respect of whom a measure of restraint in the form of custody is chosen. In order to ensure the right of a person to liberty and security, the position of an investigating judge and the institute of free legal aid have been introduced. In addition, the authors focus on the aspects of direct application of the Convention and ECtHR decisions in law enforcement practice without amending the legislation, as well as analyse the legislative perspectives arising from non-implemented ECtHR decisions.

Keywords: European convention; human rights; criminal procedure; principles of criminal procedure; Ukraine; freedom from self-disclosure; the right not to testify against close relatives and family members; the right to defence. 


\section{INTRODUCTION}

The urgent need to reform the current criminal procedure legislation of Ukraine in the late $20^{\text {th }}$ - early $21^{\text {st }}$ century was due to the fact that the then-current Code of Criminal Procedure of Ukraine was adopted in 1960 and was in force for almost half a century. It was outdated and had an imprint of the Soviet past. The bodies that conducted the trial had mainly repressive powers, the public interest dominated the rights and legitimate interests of persons involved in criminal justice, there was an inequality of rights of the parties, the defence counsel was allowed to participate in criminal proceedings only at the final stage of the criminal process and had no access to the materials of the criminal case before the end of the proceedings, there was a custom of cases being returned by the court of first instance for additional investigation, etc. This code did not comply with the Constitution of Ukraine adopted on 28 June 1996.

Recognising the need to update the regulatory framework for criminal justice, numerous working groups have proposed amendments to the Criminal Procedure Code (CrPC) of Ukraine. In particular, the changes concerned the expansion of adversarial proceedings, the rights of the victim, the elimination of accusatory bias in court activities, the expansion of judicial control over the restriction of constitutional human rights and freedoms at the pretrial stage in criminal cases, and appeals against decisions of investigators and prosecutors. Drafts of the new criminal procedure codes were also developed and presented. However, all these changes were patchwork, random, and situational. They could not fully transform the Soviet criminal process into modern criminal proceedings of a democratic state governed by the rule of law in Ukraine, where the priority is the rights, freedoms, and legitimate interests of a person and international standards for the construction of separate stages, proceedings, and procedures are taken into account. In addition, law enforcement practice and the science of criminal procedure were not ready for revolutionary change. Given the patriarchal mentality, many considered it necessary to gradually renovate criminal procedural law, which was based on national traditions, and called for caution in drawing on international experience because the new European standards, in their opinion, were so unusual that they could not be instilled at a national level and would lead to the loss of national identity. Further, the transplanting of models uncharacteristic of the Ukrainian legal system could lead to legislative divergence.

A significant number of problems existed in the structure of the criminal justice bodies called upon to carry out criminal proceedings. The system of these bodies was somewhat cumbersome, internally contradictory, not always scientifically sound, and overly complicated. The activities of its subjects were characterised by duplication of powers, lack of clear definition, and delimitation of their competence. The criminal justice authorities had an imperfect functional capacity, which did not allow them to ensure compliance with the rule of law in their activities. The numerous changes in the structure of criminal justice bodies were not systemic. They were mainly aimed at satisfying departmental interests and did not ensure the creation of an optimal system of crime prevention, detection, investigation, and punishment of perpetrators. The system of bodies traditionally called 'law enforcement' (police, Security Service of Ukraine, State Border Guard Service of Ukraine, tax police and other bodies authorised to conduct inquiries, investigations, apply administrative sanctions, etc.) were established as bodies of criminal prosecution and repression and did not aspire to the duty to protect and restore the violated rights of persons involved in the field of criminal justice. Further, the state did not introduce measures aimed at reducing the level of corruption in the field of criminal justice and state power in general. Public trust in the bodies conducting the criminal proceedings was declining every year.

It was in such conditions that the first steps of the Ukrainian legislator to reform not only the criminal process but also the entire legal system of the state began. It was obvious that 
in society, there was an urgent need for revolutionary changes in the criminal justice system and the creation of criminal procedure legislation based on national achievements and traditions. However, at the same time, these changes had to take into account European values to protect human and civil rights and fundamental freedoms and international treaties consented to by the Verkhovna Rada of Ukraine.

Such reform processes were facilitated by radical changes in the socio-political conditions of society and the state, the adoption of the Constitution of Ukraine, and the path chosen by Ukraine aimed at further democratisation, humanisation, international integration, and strengthening protection of human rights and freedoms in accordance with international law and commitment to the European and world communities.

\section{THE SIGNIFICANCE OF THE CONVENTION AS AN INSTRUMENT OF THE EUROPEAN PUBLIC ORDER}

The preamble of the Constitution of Ukraine enshrined the desire of the state to transform itself in a democratic, social, and legal direction, confirming the European identity of the Ukrainian people and the irreversibility of the European and Euro-Atlantic course of Ukraine. After Ukraine gained independence in 1991, it became the 37th member of the Council of Europe in 1995, and on 17 July 1997, it ratified the Convention for the Protection of Human Rights and Fundamental Freedoms, ${ }^{1}$ reaffirming its readiness to commit to the Council of Europe and, in particular, to implement the decisions of the European Court of Human Rights (hereafter: the ECtHR) and harmonise national legislation with the Convention on the Protection of Human Rights and Fundamental Freedoms ${ }^{2}$ (hereafter: the ECHR, the Convention).

In order to move towards reforming the entire legal system, the criminal justice system and, in particular, criminal procedural law, it was necessary to synthesise European values, conduct comparative research, understand the conceptual vectors of reform, and identify guidelines, the generalisation of which would guide the reform process. The ECHR and the case-law of the ECtHR played a leading role in this reform process. Without diving into a detailed analysis of the significance of the Convention for the legal system, as the scholarship of Ukraine and the world ${ }^{3}$ already has many fundamental works on this phenomenon, we will note only that its axiological significance for the criminal process in terms of legislative initiatives was difficult to overestimate. This is because of the nature of the criminal process, in

1 The Law of Ukraine on Ratification of the Convention for the Protection of Human Rights and Fundamental Freedoms of 1950, First Protocol and Protocols No 2, 4, 7 and 11 to the Convention of the Verkhovna Rada of Ukraine (VVR) 1997 No 40, 263.

2 The Convention for the Protection of Human Rights and Fundamental Freedoms, 4 November 1950 <https://www.echr.coe.int/documents/convention_eng.pdf> accessed 12 February 2021.

3 See: C Grabenwarter, 'The European Convention on Human Rights: Inherent Constitutional Tendencies and the Role of the European Court of Human Rights' in A von Bogdandy, P Sonnevend (eds), Constitutional Crisis in the European Constitutional Area, Theory, Law and Politics in Hungary and Romania (2015) 257-275; <https://eltelawjournal.hu/wp-content/ uploads/2014/10/7_Christoph_Grabenwarter.pdf> accessed 12 February 2021. H Keller, A Sweet, 'Assessing the Impact of the ECHR on National Legal Systems' in A Europe of Rights: The Impact of the ECHR on National Legal Systems (Oxford University Press 2008) 677-712. <https://digitalcommons. law.yale.edu/cgi/viewcontent.cgi?article=1087\&context=fss_papers $>$ accessed 12 February 2021; W Luzius, 'Rethinking the European Court of Human Rights' in The European Court of Human Rights between Law and Politics (2011) 204-230; EA Alkema, 'The European Convention as a Constitution and Its Court as a Constitutional Court' in P Mahoney et al (eds), Protection des droits de l'homme: la perspective européenne: mélanges à la mémoire de Rolv Ryssdal (Cologne 2000) 41-65; M De Salvia, 'Compendium de la CEDH: les Principes Directeurs de la Jurisprudence Relative à la Convention Européenne des Droits de l'Homme' in Jurisprudence 1960 à 2002 (2003) 865. 
which the risks of human rights and freedoms and the risk of abuse of coercion are extremely high. Ensuring a fair trial and access to justice is the key to restoring public confidence in the judiciary, as well as maintaining the authority of the state as a whole.

On 23 February 2006, the Verkhovna Rada of Ukraine adopted the Law of Ukraine 'On Enforcement of Decisions and Application of the Case Law of the European Court of Human Rights.' This Law regulates the relations arising in connection with the obligation of the state to comply with the decisions of the ECtHR in cases against Ukraine; with the need to eliminate the reasons for Ukraine's violation of the Labour Code and its protocols; with the introduction of European human rights standards into Ukrainian justice and administrative practice; creating the preconditions for reducing the number of applications to the ECtHR against Ukraine.

The provisions of this Law of Ukraine largely relate to the final decisions of the ECtHR in cases against Ukraine, which recognised violations of the ECHR. This is understandable because based on the Law of Ukraine 'On Ratification of the Convention for the Protection of Human Rights and Fundamental Freedoms of 1950', Ukraine fully recognises the binding jurisdiction of the European Court on all matters concerning the interpretation and application of the ECHR. Thus, the judgments of the European Court that may be given in respect to Ukraine are given the same legal status as the ECHRitself.

However, as is well known, the ECHR is a living instrument, which is continually developed in the ECtHR case law and must be interpreted in the light of present-day conditions. ${ }^{5}$

\section{Christoph Grabenwarter highlighted that}

through manifold influences on the legal orders and the process of implementation into the constitutions of European states [...] it seems appropriate to describe the Convention, by reference to the ECtHR, as a 'constitutional instrument of European public order' and, by reference to literature, as part of the ordre public européen, as a 'European constitution of human rights', a 'substantive common European constitution', a 'constitution of human rights' or as a 'process of constitutionalization' [...] the Convention may be described as a European constitutional instrument of human rights and thus as a partial constitution in the field of human rights; the ECtHR may be referred to as a 'European constitutional court' for human rights. ${ }^{6}$

Rights and freedoms guaranteed by the ECHR are not theoretical or illusory but practical and effective, hereby obligating the contracting states to provide effective protection of human rights on a national level. ${ }^{7}$

\section{The ECtHR itself reiterates that}

the Court's judgments in fact serve not only to decide those cases brought before the Court but, more generally, to elucidate, safeguard and develop the rules instituted by the Convention, thereby contributing to the observance by the States of the engagements undertaken by them as Contracting Parties. ${ }^{8}$

4 The Law of Ukraine 'On the implementation of decisions and application of the case law of the European Court of Human Rights' [2006] Vidomosti of the Verkhovna Rada 18/123 <https://zakon.rada.gov.ua/ laws/show/3477-15\#Text> accessed 12 February 2021.

5 Tyrer $v$ UK App no 5856/72 (ECtHR, 25 April 1978) para $31<$ http://hudoc.echr.coe.int/eng?i=001-57587> accessed 12 February 2021. See also European Court of Human Rights, 'The ECHR in 50 questions' $<$ https://www.echr.coe.int/Documents/50Questions_ENG.pdf> accessed 12 February 2021.

6 Grabenwarter (n 3) 103.

7 Dvorski v Croatia App no 25703/11 (ECtHR, 20 October 2015) para $82<$ http://hudoc.echr.coe.int/ eng?i=001-158266 > accessed 12 February 2021.

8 Ireland $v$ UK App no 5310/71 (ECtHR, 20 March 2018) para 12 <http://hudoc.echr.coe.int/ eng?i=001-181585> accessed 12 February 2021. 


\section{ECHR AND THE PRACTICE OF THE ECTHR AS A GUIDE FOR THE REFORMATION OF CRIMINAL JUSTICE IN UKRAINE}

\subsection{The principles of criminal proceedings: freedom from self-disclosure and the right not to testify against close relatives and family members; immediacy of testimonies, objects and documents examination; presumption of innocence, ensuring the right to defence and their implementation in the new CrPC of Ukraine 2012}

One of the directions of the ECtHR practice's influence on national normative-legal guarantees of human rights and freedoms is the positive law-making reaction of the competent state body to the ECtHR's recommendations and instructions on improving the mechanisms for ensuring human rights and freedoms. It should be noted that of all the ECtHR's violations in the cases against Ukraine during 2008-2013, at least a fifth were caused by shortcomings in the national human rights legislation, which indicated the need to change the legislation without undue delay. It is determined by the fact that in the CrPC of 1960, the system of principles of criminal proceedings was significantly limited, and some of them, such as the presumption of innocence, were not mentioned at all.

A number of ECtHR decisions contributed to the formation of the new CrPC system of general principles of criminal proceedings as fundamental, general provisions that contain the essential features of criminal proceedings, determine the level of protection of human rights and freedoms, build its system (stages and separate proceedings), and guide the activities of participants in criminal proceedings.

Such decisions include Lutsenko $v$ Ukraine, in which Lutsenko was convicted of murder. ${ }^{9}$ The Supreme Court upheld the verdict, and Lutsenko consequently appealed to the ECtHR, arguing that he had not received a fair trial; he was convicted on the basis of the testimony of another accused. However, the latter was not questioned during the trial, and the court used his written testimony, which he had given during the pre-trial investigation as a witness, to convict Lutsenko. The ECtHR stated in its decision that Lutsenko's accomplice, who was also suspected of committing the same crime, testified as a witness and was therefore subject to criminal liability for refusing to testify, which violated his right to remain silent. Because of these violations, Lutsenko's conviction was the result of an unfair trial: 'The credibility of evidence is undermined if it is obtained in violation of the right to "silence" and the privilege against self-incrimination'. The right not to testify against oneself requires, in particular, that the prosecution in a criminal case does not allow the use of evidence obtained by means of pressure or coercion against the will of the accused in trying to prove its version of events $(\$ 49) .{ }^{10}$ At the same time, the Court stated that the domestic courts violated the applicant's right to cross-examine the person who had testified against him.

In pursuance of Lutsenko $v$ Ukraine, the new CrPC of Ukraine reflects a number of norms, including Art. 18 'Freedom from self-disclosure and the right not to testify against close relatives and family members. The CrPC enshrined a rule that provided that no person could be forced to admit their guilt in committing a criminal offence or forced to give explanations or a testimony that could be grounds for suspicion or an accusation of committing a criminal offence. Everyone has the right not to say anything about the suspicion or accusation against them, to refuse to answer questions at any time and to be immediately informed of these rights. No person may be compelled to give explanations or testimonies that might give

$9 \quad$ Lutsenko v Ukraine App no 6492/11 (ECtHR, 2 July 2011).

10 In December 2011, the Supreme Court of Ukraine canceled all court decisions in Lutsenko's case and remanded the case to the court of first instance. 
rise to suspicion or accusation of committing a criminal offence by their close relatives or members of their family.

In addition, for the first time in the $\mathrm{CrPC}$ of Ukraine, there was a rule-principle that provided for the immediacy of the court's examination of testimony, objects, and documents. ${ }^{11}$ The law forbade the admission of evidence contained in testimony, objects, and documents that were not the subject of direct investigation by the court. As an exception, the court could accept as evidence the testimony of persons who did not depose directly at the hearing only in cases provided by the Code (Art. 23). In addition, for the first time in the history of the criminal process in Ukraine, there was the requirement to recognise a violation of the right to cross-examination as a significant violation of the right of a person, which entails the inadmissibility of evidence (para. 5 of Part 2 of Art. 87 of the CrPC).

A similar position was taken by the ECtHR in the case of Leonid Lazarenko $v$ Ukraine, Yaremenko $v$ Ukraine, and Shabelnyk $v$ Ukraine, ${ }^{12}$ where it stated, inter alia, that

the principles of the right to defense and the right not to testify against oneself meet universally recognized international human rights standards, which are the main components of the concept of a fair trial and the rational essence of which is related, in particular, to the protection of the accused from arbitrary pressure from the authorities. They also help to prevent errors in the administration of justice and the objectives of Article 6, in particular the observance of the principle of equality between the investigating and prosecuting authorities and the accused. The right not to testify provides, inter alia, that the prosecution must prove its case against the accused without resorting to evidence obtained by means of coercion or pressure against the will of the accused (para. 51). ${ }^{13}$

As regards the use of evidence obtained in violation of the detainee's right to remain silent and the right not to testify against himself, the Court reiterates that the existence of such rights is a universally recognized international standard - the core of the concept of a fair trial under Article 6. The establishment of such standards is explained, in particular, by the need to protect the accused from unlawful coercion by the authorities, which should help to avoid errors in the administration of justice and promote the objectives of Article 6. The right not to testify requires, in particular, to substantiate their arguments against the accused without resorting to evidence obtained by means of coercion or pressure, against the will of the accused (para. 77). ${ }^{14}$

Despite enshrining the provisions that constitute the meaning of presumption of innocence in the Constitution of Ukraine (Art. 62), the demand for its provisions in law enforcement practice, and its development at the doctrinal level, the CrPC of Ukraine of 1960 did not contain the phrase 'presumption of innocence'. However, the need for Ukraine to fulfil its international obligations and the decisions of the ECtHR in the cases of Grabchuk v Ukraine, Panteleenko $v$ Ukraine, Shagin $v$ Ukraine, and Dovzhenko $v$ Ukraine $^{15}$ contributed to the emergence of a new

11 Nechiporuk and Yonkalo v Ukraine App no 42310/04 (ECtHR, 21 April 2011) <http://hudoc.echr.coe. int/eng?i=001-104613> accessed 12 February 2021.

12 Lazarenko $v$ Ukraine App no 26855/05 (ECtHR, 19 November 2009) <http://hudoc.echr.coe.int/ eng?i=001-95732> accessed 12 February 2021; Yaremenko $v$ Ukraine App no 32092/02 (ECtHR, 12 June 2008) <http://hudoc.echr.coe.int/eng?i=001-86885> accessed 12 February 2021; Shabelnik $v$ Ukraine App no 16404/03 (ECtHR, 19 February 2009) <http://hudoc.echr.coe.int/eng?i=001-91401> accessed 12 February 2021.

13 Lazarenko $v$ Ukraine App no 26855/05 (ECtHR, 19 November 2009) <http://hudoc.echr.coe.int/ eng?i=001-95732> accessed 12 February 2021.

14 Yaremenko $v$ Ukraine (n 12).

15 Grabchukv Ukraine App no (ECtHR, 21 September 2006) <http://hudoc.echr.coe.int/eng?i=001-76950> accessed 12 February 2021; Panteleyenko v Ukraine App no 11901/02 (ECtHR, 29 June 2006) <http:// hudoc.echr.coe.int/eng?i=001-76114> accessed 12 February 2021; Shagin v Ukraine App no 20437/05 (ECtHR, 10 December 2009) <http://hudoc.echr.coe.int/eng?i=001-96112> accessed 12 February 2021; Dovzhenko v Ukraine App no 36650/0312 (ECtHR, January 2012) <http://hudoc.echr.coe.int/ eng?i=001-108549> accessed 12 February 2021. 
Art. 17 'Presumption of innocence and proof of guilt' in the CrPC, which provided a general rule that a person is presumed innocent of committing a criminal offence and cannot be prosecuted until proven guilty in the procedure provided by the CrPC and established by the conviction of the court, which entered into force. It also enshrined the important provisions that must be reflected in the evidence: no one is obliged to prove his innocence in a criminal offence and must be acquitted if the prosecution does not prove the guilt of a person beyond a reasonable doubt; suspicion and accusations cannot be based on evidence obtained illegally; all doubts as to the guilt of a person shall be construed in favour of such person; treatment of a person whose guilt in committing a criminal offence has not been established by a conviction of a court that has entered into force must correspond to the treatment of an innocent person.

In pursuance of the decision of Shabelnyk $v$ Ukraine and in order to prevent systemic violations taking place during the interrogation of persons forced to testify against themselves, the new CrPC of Ukraine also has a rule according to which evidence obtained from a witness who was further recognised as a suspect or accused in criminal proceedings are inadmissible (para. 1 of Part 3 of Art. 87 of the CrPC).

For the first time at the legislative level, the CrPC of Ukraine enshrined the principle of reasonable time for case examination. In Izzetov v Ukraine (2011), the ECtHR, emphasising that the reasonableness of the length of proceedings should be assessed in light of the circumstances of the case, proposed criteria such as the complexity of the case, the conduct of the applicant and the relevant authorities during the trial, and the importance of the subject matter for the applicant (para. 68). ${ }^{16}$ Relying on the decisions in the cases of Antonenkov and Others v Ukraine, ${ }^{17}$ Ivanov v Ukraine, ${ }^{18}$ Boldyrev v Ukraine, ${ }^{19}$ NV v Ukraine, ${ }^{20}$ Bugaev $v$ Ukraine, ${ }^{21}$ Aibabin v Ukraine, ${ }^{22}$ Baglay $v$ Ukraine, ${ }^{23}$ and others, Ukrainian legislators introduced Art. 28 of the CrPC, which implemented the ECtHR's definition of reasonable time limits for criminal proceedings and their criteria. This position is also confirmed in other decisions of the ECtHR. Moreover, the legislator reproduced the provisions developed by the practice of the ECtHR almost word-for-word. According to Art. 28 of the CrPC, reasonable time limits are considered to be objectively necessary for the performance of procedural actions and the adoption of procedural decisions. Criteria for reasonable time are: 1) the complexity of criminal proceedings; 2 ) behaviour of participants in criminal proceedings; 3 ) the manner in which the prosecutor and the court exercise their powers. In addition, it should be noted that although the fourth criterion is not enshrined in the rules of criminal procedure, it is applied by judges directly, based on the provisions of the ECHR. This criterion is based on factors such as the importance of resolving the case for the applicant (Bugaev $v$ Ukraine).

\subsection{Obligations of Ukraine regarding the creation of a system of free legal aid}

As is well known, under para. 3 (c) of Art. 6 of the ECHR,

Everyone charged with a criminal offense has the following minimum rights: ... (c) to defend himself in person or through legal assistance of his own choosing or, if he has not sufficient means to pay for legal assistance, to be given it free when the interests of justice so require.

16 Izzetov v Ukraine App no 23136/04 (ECtHR, 15 September 2011) <http://hudoc.echr.coe.int/ eng?i=001-106165> accessed 12 February 2021.

17 Antonenkov and Others $v$ Ukraine App no 14183/02 (ECtHR, 22 November 2005).

18 Ivanov v Ukraine App no 1500/02 (ECtHR, 7 December 2006).

19 Boldyrev v Ukraine App no 27889/03 (ECtHR, 20 January 2011).

20 NV v Ukraine App no 17945/02 (ECtHR, 3 April 2008).

21 Bugaev v Ukraine App no 7516/03 (ECtHR, 8 July 2010).

22 Aibabin v Ukraine App no 23194/02 (ECtHR, 18 March 2009).

23 Baglay $v$ Ukraine App no 22431/02 (ECtHR, 8 November 2005). 
A number of complaints to the ECtHR from Ukrainian citizens concerned the non-provision of free legal aid during criminal proceedings, including in the Supreme Court of Ukraine. In this regard, in the case of Maksimenko $v$ Ukraine, ${ }^{24}$ the ECtHR stated that

The right of those charged with criminal offences to free legal assistance, which is one of those guarantees, is subject to two conditions: the person concerned must lack sufficient means to pay for legal assistance, and the interests of justice must require that he or she be granted such assistance (para 25).

The interests of justice, in principle, require securing legal representation in the case of deprivation of liberty, especially when it comes to the possibility of sentencing to life imprisonment. The Court criticised the CrPC of Ukraine of 1960, noting that the violation of the right enshrined in para. 3 (c) of Art. 6 of the ECHR was due to the absence of any procedures for appointing free legal representation at that stage of the proceedings where it was no longer deemed mandatory under the CrPC. ${ }^{25}$

The need to comply with the provisions of the ECHR contained in para. 3 (c) of Art. 6 of the ECHR and the systemic violations found in the cases of Maksymenko v Ukraine, Iglin $v$ Ukraine, Nikolaenko $v$ Ukraine, ${ }^{26}$ led to the development and adoption on 2 June 2011 of the Law of Ukraine 'On Free Legal Aid, ${ }^{27}$ as well as a significant expansion of the rights of the defence. In particular, in accordance with Art. 20 of the CrPC 2012, in cases provided by the $\mathrm{CrPC}$ and/or the law governing the provision of free legal aid, the suspect is entitled to legal aid free of charge at the expense of the state.

Based on the ECtHR's consideration of a number of cases, in particular, Balytsky $v$ Ukraine, Yaremenko v Ukraine, Lutsenko v Ukraine, Shabelnyk v Ukraine, Leonid Lazarenko v Ukraine; Borotyuk v Ukraine; Bortnik v Ukraine, Todorov v Ukraine; Khairov v Ukraine; Serhiy Afanasyev $v$ Ukraine; Yerokhina $v$ Ukraine, during the drafting of the CrPC of Ukraine, the legislator developed rules regarding: 1) the right of the suspect or the accused to have a lawyer and visit him or her before the first interrogation in compliance with the conditions ensuring confidentiality of communication, and after the first interrogation, without limiting their number and duration (para. 3, Part 3 of Art. 42 of the CrPC of Ukraine of 2012);2) the obligation of the investigator, prosecutor, investigating judge, or court to engage a defence counsel, if his/her participation is mandatory but the suspect or the accused has not engaged a defence counsel; the suspect or the accused has filed a motion to engage a defence counsel, but due to lack of funds or for other objective reasons, he/she cannot engage him or her independently; the investigator, prosecutor, investigating judge, or court decides that the circumstances of the criminal proceedings require the participation of a defence counsel, and the suspect or the accused did not engage him or her (Part 1 of Art. 49 of the CrPC of Ukraine of 2012); the expansion of cases of mandatory involvement of a defence counsel (Part 1 of Art. 52 of the CrPC of Ukraine 2012); abolition of the institute of the guilty plea, as the law did not provide for the right to a lawyer in such cases, which was repeatedly criticised by the ECtHR.

In addition, these cases contributed to the formation of new regulations on the admissibility of evidence, which are reflected in Art. 87 of the CrPC of Ukraine 2012. ${ }^{28}$

24 Maksimenko $v$ Ukraine App no 39488/07 (ECtHR, 20 December 2011) <http://hudoc.echr.coe.int/ eng?i=001-108239> accessed 12 February 2021.

25 ibid, paras 28-32.

26 Maksimenko $v$ Ukraine (n 24), Iglin v Ukraine App no 39908/05 (ECtHR,12 January 2012) <http://hudoc. echr.coe.int/eng?i=001-108506> accessed 12 February 2021; Nikolayenko $v$ Ukraine App no 39994/06 (ECtHR, 15 November 2012) <http://hudoc.echr.coe.int/eng?i=001-114457> accessed 12 February 2021.

27 The Law of Ukraine No 3460-VI of 2 June 2011 'On Free Legal Aid' [2011] Vidomosti Verkhovnoi Rady 51:577.

28 Department for the Execution of the Judgments of the ECHR Case of Balitskiy $v$ Ukraine (leading case) $<$ http://hudoc.exec.coe.int/eng?i=004-31116> accessed 12 February 2021. 
The decision of the ECtHR in the case Zagorodny v Ukraine (24.11.11) determined the inclusion in the CrPC of Ukraine of 2012 of a rule according to which a lawyer in criminal proceedings must be a lawyer listed in the Unified Register of Lawyers of Ukraine (Art. 45). Subsequently, relevant amendments were also made to the Constitution of Ukraine, which provided that 'everyone has the right to professional legal assistance. In cases provided by law, this assistance is provided free of charge. Everyone is free to choose a defender of their rights' (Art. 59).

\title{
3.3 Positive legislative reaction of Ukraine to the recommendations made by the ECtHR regarding the standardisation of measures to ensure criminal proceedings and precautionary measures
}

The impact of the ECtHR's practice on Ukraine's criminal procedure legislation has caused a paradigm shift in criminal procedure. This shift included expanding court jurisdiction to ensure a system of guarantees for the protection of individual rights and adversarial proceedings at the pre-trial stage. Art. 5 of the ECHR states that

\begin{abstract}
Everyone arrested or detained in accordance with the provisions of paragraph 1 (c) of this Article shall be brought promptly before a judge or other officer authorised by law to exercise judicial power and shall be entitled to trial within a reasonable time or to release pending trial. [...] Everyone who is deprived of his liberty by arrest or detention shall be entitled to take proceedings by which the lawfulness of his detention shall be decided speedily by a court and his release ordered if the detention is not lawful.
\end{abstract}

These provisions can be considered one of the determinants that influenced the introduction of almost revolutionary changes for the criminal process of the post-Soviet state institution of investigating judge in the criminal process of Ukraine, which performs the function of judicial control over the rights, freedoms, and interests of persons in criminal proceedings. In addition, a number of ECtHR decisions on Ukraine have accelerated changes in legislation. In particular, the ECtHR judgment in the case of Merit v Ukraine of 30 March 2004 (para 63) ${ }^{29}$ stated that

\footnotetext{
prosecutors perform investigative and prosecuting functions and, therefore, their position in the criminal proceedings as provided for by the law at the material time, in particular by the provisions of Law on Prosecution (Chapters I-II) and the Code of Criminal Procedure of Ukraine (Articles 22, 25 and 32 of the Code), must be seen as that of a party to these proceedings.
}

The ECtHR thus concludes that: a) recourse to a prosecutor with complaints is not an effective remedy, as the status of a prosecutor in national law and his or her participation in criminal proceedings do not provide adequate guarantees for the independent and impartial consideration of complaints; b) the attribution to the prosecutor of the right to choose a measure of restraint in the form of detention does not comply with para. 3 of Art. 5 of the ECHR, as he or she is a party to the proceedings and it cannot be expected from a person who plays such a role to be impartial in the exercise of judicial power in the same case.

Thus, the introduction of the institution of an investigative judge with a fairly broad subject of jurisdiction, a 'neutral arbitrator' who performs neither the function of prosecution nor the function of defence and is the bearer of judicial power, helped to ensure prompt, urgent judicial protection in case of restriction of constitutional rights during pre-trial investigation. It also secured the implementation of the principles of the rule of law and adversarial proceedings at this stage of criminal proceedings, which increased the level of legal protection of its participants.

In contrast to the periodic judicial control provided for by the CrPC of Ukraine of 1960 , the activity of an investigating judge under the new CrPC is cross-cutting, which has a

29 MeritvUkraine App no 66561/01 (ECtHR, 30 March 2004)<http://hudoc.echr.coe.int/eng?i=001-61685> accessed 12 February 2021. 
positive effect on the level of guarantee of constitutional human rights and freedoms in criminal proceedings. Given the tasks facing the investigating judge, this subject of criminal proceedings is capable of preventing and protecting against violations or unjustified restrictions of constitutional human rights and freedoms that are likely to be allowed by actions or decisions of the coroner, investigator, or prosecutor.

The investigating judge exercising the powers within the given competence, including in the application of measures to ensure criminal proceedings, granting permission to conduct certain investigative (searching), and covert investigative (searching) actions, uses a threepart test to assess the justification of interference with human rights, which was developed by the case-law of the ECtHR, in particular, in the judgments in Panteleenko $v$ Ukraine of 29 June $2006^{30}$ and Ratushna $v$ Ukraine of 2 December 2010. ${ }^{31}$ The test includes such constituents as: 1) the interference was carried out in accordance with the law'; 2) it meets a legal, legitimate purpose; 3 ) it is 'necessary in a democratic society'.

In exercising his/her powers, the investigating judge (at the stage of the pre-trial investigation) or the court (during the trial) shall verify the existence of the conditions guaranteed by the ECHR for the restriction of the rights and freedoms of the person in criminal proceedings. Thus, in particular, in para. 42 of the judgment in the case of Kryvitska and Kryvitsky $v$ Ukraine of 2 December 2010, the ECtHR stated

A State interference constitutes a violation of Article 8 of the Convention, unless it pursues one of the legitimate aims enumerated in Article $8 \$ 2$, is "in accordance with the law", and can be regarded as "necessary in a democratic society". ${ }^{2}$

The ECtHR takes a similar position in other cases, for example, in para. 47 of the judgment of Savina v Ukraine ${ }^{33}$ of 18 December 2008; para. 51 of the decision Verentsov $v$ Ukraine $^{34}$ of 11 April 2013; para. 81 of the judgment Serhiy Volosyuk v Ukraine $e^{35}$ of 12 March 2009, etc.

The case-law of the ECtHR has given a new impetus to the understanding of the institution of precautionary measures in the new CrPC of Ukraine of 2012, the essence of which is deduced through the prism of measures to ensure criminal proceedings, which are used to achieve its effectiveness. One of the pilot decisions in this respect is the decision of the ECtHR in the case of Kharchenko $v$ Ukraine, which emphasised that considering the systemic nature of the problem identified in this case (systemic human rights violations in detention), specific reforms in Ukrainian law and administrative practice should be implemented immediately to bring them into line with the Court's findings in this judgment in order to ensure that such legislation and practice comply with Art. 5 of the ECHR (para. 101). ${ }^{36}$ As a starting point, we note that the main purpose of Art. 5 of the ECHRis the prevention of arbitrary or unjustified deprivation of liberty. ${ }^{37}$

30 Panteleyenko $v$ Ukraine App no 11901/02 (ECtHR, 29 June 2006) <http://hudoc.echr.coe.int/ eng?i=001-76114> accessed 12 February 2021.

31 Ratushna $v$ Ukraine App no 17318/06 (ECtHR, 2 February 2010) <http://hudoc.echr.coe.int/ eng?i=001-102023> accessed 12 February 2021.

32 Kryvitska and Kryvitskyy v Ukraine App no 30856/03 (ECtHR, 2 December 2010) <http://hudoc.echr. coe.int/eng?i=001-101978> accessed 12 February 2021.

33 Saviny $v$ Ukraine App no 39948/06 (ECtHR, 18 December 2008) <http://hudoc.echr.coe.int/ eng?i=001-90360 > accessed 12 February 2021.

34 Vyerentsov $v$ Ukraine App no 20372/11 (ECtHR, 11 April 2013) <http://hudoc.echr.coe.int/ eng?i=001-118393> accessed 12 February 2021.

35 Volosyuk $v$ Ukraine App no 28403/05 (ECtHR, 12 March 2009) <http://hudoc.echr.coe.int/ eng?i=001-76092> accessed 12 February 2021.

36 Borotyuk $v$ Ukraine App no 33579/04 (ECtHR, 16 March 2011) <http://hudoc.echr.coe.int/ eng?i=001-102288 $>$ accessed 12 February 2021.

37 McKay v United Kingdom App no 543/03 (ECtHR, 3 October 2006) <http://hudoc.echr.coe.int/ eng?i=001-77177> accessed 12 February 2021. 
The key role for the law enforcement practice of Ukraine was played by the decisions of the ECtHR in the cases of Letelle $v$ France $e^{38}$ of 26 June 1991, Tomazi v France ${ }^{39}$ of 27 August 1992, White $v$ Ukraine $^{40}$ of 21 January 2011, and Borotyuk $v$ Ukraine $^{41}$ of 16 March 2011, as the legal conclusions formulated in these cases have changed the approaches to the application by national courts of a measure of restraint in the form of detention, which could previously have been chosen based only on the gravity of the crime. Founded on the case-law of the ECtHR and the new criminal procedure legislation, investigating judges in Ukraine take into account all the circumstances of criminal proceedings, avoiding standard lists of risks, and the prosecution must substantiate each of them separately with evidence. As stated in the ECtHR judgment in Kharchenko $v$ Ukraine ${ }^{42}$ of 10 February 2011, a continued detention can be justified only in the presence of a specific public interest which, despite the presumption of innocence, prevails over the principle of respect for individual liberty; national judicial authorities must examine all the factors for or against the existence of a genuine requirement of public interest, justifying, with due regard to the principle of the presumption of innocence, a departure from the rule of respect for individual liberty, and must set them out in their decisions dismissing the applications for release (para. 60 of the decision in the case Borotyuk $v$ Ukraine). ${ }^{43}$

According to the logic of the ECtHR, the use of detention as a precautionary measure is possible only if there are sufficient grounds to restrict the right to liberty and security of person. In particular, para. 61 of the judgment in Ruslan Yakovenko v Ukraine states that in order for detention not to be arbitrary, it is necessary to observe the proportionality between the stated grounds for detention and the actual detention (including the possible punishment that threatens the person). ${ }^{44}$ The requirement of detention was taken into account only by the domestic legislator and reflected in Arts. 177, 183, and 194 of the CrPC of Ukraine, according to the normative content of which the prosecutor must prove the need to apply appropriate precautionary measures, and the investigating judge and the court, based on 'the presumption of the release of the accused' (see Kalashnikov v Russia, 15 July 2002), ${ }^{45}$ must establish appropriate and sufficient grounds for its application.

The ECHR case-law has developed four basic acceptable reasons for refusing bail, which are defined in para. 59 of the judgment in Smirnova $v$ Russia of 24 July 2003, namely: a) the risk that the accused will fail to appear for trial, b) the risk that the accused, if released, would take action to prejudice the administration of justice, c) commit further offences or d) cause public disorder. ${ }^{46}$ These provisions are fully reproduced in Art. 177 of the CrPC of Ukraine. An essential element of the Convention's guarantee of non-arbitrary detention is the following requirement: in the absence of reasonable suspicion, a person may under no circumstances be detained in order to force him/her to confess to a crime, testify against

38 Letellier v France App no 12369/86 (ECtHR, 26 June 1991) <http://hudoc.echr.coe.int/eng?i=001-57678> accessed 12 February 2021.

39 Tomasi $v$ France App no 12850/87 (ECtHR, 27 September 1992) < http://hudoc.echr.coe.int/ eng?i=001-57796 accessed 12 February 2021> accessed 12 February 2021.

40 Bilyy $v$ Ukraine App no 14475/03 (ECtHR, 21 January $2011<\mathrm{http}: / /$ hudoc.echr.coe.int/ eng?i=001-101175 $>$ accessed 12 February 2021.

41 Borotyuk v Ukraine (n 36).

42 ibid.

43 Borotyuk v Ukraine (n 36).

44 Ruslan Yakovenko v Ukraine App no 5425/11 (ECtHR, 4 June 2015) <http://hudoc.echr.coe.int/ eng?i=001-154978> accessed 12 February 2021.

45 Kalashnikov $v$ Russia App no 47095/99 (ECtHR, 15 July 2002) <http://hudoc.echr.coe.int/ eng?i=001-60606> accessed 12 February 2021.

46 Smirnova $v$ Russia App nos 46133/99 and 48183/99 (ECtHR, 24 July 2003) <http://hudoc.echr.coe.int/ eng?i=001-61262> accessed 12 February 2021. 
others or to obtain facts or information that may give rise to reasonable suspicion. ${ }^{47}$ At the same time, 'reasonable suspicion' means that there are facts or information that can convince an objective observer that the person in question may have committed an offence (see Nechyporuk and Yonkalo $v$ Ukraine). ${ }^{48}$

Implementing this requirement, the domestic legislator in Part 2 of Art. 177 of the CrPC of Ukraine laid down an important guarantee against the arbitrary application of a precautionary measure: 'The basis for the application of a precautionary measure is the existence of reasonable suspicion that a person has committed a criminal offense.... The above legislative structure radically changed the vicious practice that existed before the adoption of the CrPC of Ukraine in 2012, when even the highest court recommended that when considering a request for detention, a judge may not examine evidence, evaluate it, or otherwise verify the guilt of a suspect or accused to consider and resolve those issues that must be resolved by the court during the consideration of the criminal case on the merits (see the decision of the Plenum of the Supreme Court of 25 April 2003 No 4, p. 10). ${ }^{49}$

Based on the content of the ECtHR judgment in Mironenko and Martenko v Ukraine of 10 December $2009^{50}$

the competent court has to examine not only compliance with the procedural requirements of domestic law but also the reasonableness of the suspicion underpinning the arrest, and the legitimacy of the purpose pursued by the arrest and the ensuing detention..$^{51}$

Therefore, the CrPC of Ukraine stipulates that the request of the investigator or prosecutor to apply a measure of restraint must contain specific circumstances that give grounds to suspect a person of committing a criminal offense and references to materials confirming these circumstances (para. 3, Part 1 Art. 184 of the CrPC).

Reasonable suspicion is an important guarantee against the arbitrary application of precautionary measures, but the proof of its existence at the time of choosing a specific precautionary measure does not lead to further indictment or sentence. This guides the practice of the ECtHR. Thus, in the judgment in the case of Chebotari v Moldova of 13 November 2007, it was stated that

in order for an arrest on reasonable suspicion to be justified under Article $5 \$ 1$ (c) it is not necessary for the police to have obtained sufficient evidence to bring charges, either at the point of arrest or while the applicant is in custody. [...] Neither is it necessary that the person detained should ultimately have been charged or brought before a court. ${ }^{52}$

Another illustrative example is the case-law of the ECtHR (Rashad Khasanov and Others $v$ Azerbaijan, 7 June 2018), ${ }^{53}$ which found a violation of the ECHR on grounds of suspicion.

47 Nechiporuk and Yonkalo v Ukraine App no 42310/04 (ECtHR, 21 April 2011) <http://hudoc.echr.coe. int/eng?i=001-104613> accessed 12 February 2021.

48 ibid.

49 On the practice of application by courts of a measure of restraint in the form of custody and extension of terms of custody at the stages of inquiry and pre-trial investigation: resolution of the Plenum of the Supreme Court of Ukraine of 25 April 2003 No 4 in Legislation of Ukraine: normative rights base, Supreme Council of Ukraine <http://zakon5.rada.gov.ua/laws/show/v0004700-03> accessed 12 February 2021.

50 Mironenko and Martenko v Ukraine App No 4785/02 (ECtHR, 10 December 2009) <http://hudoc.echr. coe.int/eng?i=001-96195 > accessed 12 February 2021.

51 A similar legal position is contained in Yeloyev $v$ Ukraine. See: Yeloyev $v$ Ukraine App no 17283/02 (ECtHR, 6 November 2008) <http://hudoc.echr.coe.int/eng?i=001-89452> accessed 12 February 2021.

52 Chebotari v Moldova App no 35615/06 (ECtHR, 13 November 2007) <http://hudoc.echr.coe.int/ eng?i=001-83247> accessed 12 February 2021.

53 Rashad Hasanov and Others $v$ Azerbaijan App nos 48653/13, 52464/13, 65597/13, 70019/13 (ECtHR, 7 June 2018) <http://hudoc.echr.coe.int/eng?i=001-183372> accessed 12 February 2021. 
Thus, there has been a violation of Arts. 5 and 18 of the CrPC on the ground that the applicants' freedom was restricted for other purposes under the ECHR. In particular, their arrest and detention were intended to punish these individuals for their political and social activities as members of the NIDA board, as well as to end protests against the deaths of soldiers and destroy the active youth movement in the country. The Court noted that these objectives differed from bringing them before the statutory competent authority on the basis of a reasonable suspicion of having committed a crime. The Court considered this to be a sufficient ground for finding a violation of these articles of the ECHR. ${ }^{54}$

To continue the analysis of the grounds for the use of detention, we note that the basic risks provided for in Art. 5 of the ECHR are fully implemented in the national legislation of Ukraine. In particular, in accordance with Art. 177 of the CrPC of Ukraine, the purpose of the precautionary measure is to ensure the fulfilment of procedural obligations of the suspect or the accused, as well as to prevent attempts to: 1) hide from the pre-trial investigation and/ or court; 2) destroy, hide or distort any of the things or documents that are essential for establishing the circumstances of a criminal offence; 3 ) illegally influence a victim, witness, another suspect, accused, expert, or specialist in the same criminal proceedings; 4) obstruct criminal proceedings in any other way; 5) commit another criminal offence or continue a criminal offence in which he/she is suspected or accused. ${ }^{55}$

Another convention contained in para. 4 of Art. 5 of the ECHR that has been implemented in the CrPC of Ukraine concerns the provision of equal opportunities for the parties to criminal proceedings to independently defend their legal positions before the court. That is, it is necessary to ensure the mandatory presence of the suspect or the accused in deciding on the application of precautionary measures. In particular, in para. 277 of the judgment in Tymoshenko $v$ Ukraine, the ECtHR stated that one of the purposes of a reasonable decision on this issue was to demonstrate to the parties that their positions had been taken into account. The new CrPC of Ukraine guarantees the right of the suspect to be present during the consideration of the request for the application of a precautionary measure, except for the cases provided for in Part 6 of Art. 193 of the CrPC of Ukraine. But, as can be seen from the content of Art. 199 of the CrPC of Ukraine, the issue of the suspect's participation in the consideration of the petition for an extension of the detention term remains unresolved.

Judicial review of the lawfulness of a preventive measure in the form of detention is linked to another standard - detention for a reasonable period of time. It is noteworthy that the CrPC does not directly mention this international standard, but the ECtHR, verifying compliance by Member States with paras. 1 and 3 of Art. 5 of the ECHR, examines the period during which it is legitimate to restrict a person's right to liberty and personal security. At the same time, the case-law of the ECtHR does not specify which period of detention should be defined as reasonable but only emphasises that it should be justified. Thus, in para. 266 of the judgment in the case of Tymoshenko v Ukraine, the Court stated: 'the justification of any period of imprisonment, regardless of how short it is, must be convincingly proved by the state authorities. ${ }^{56}$ Para. 45 of the judgment in Tkachev $v$ Ukraine states that

it falls in the first place to the national judicial authorities to ensure that, in a given case, the pre-trial detention of an accused person does not exceed a reasonable time.

54 _ibid.

55 In this context, it should be noted that the ECtHR also considers the risk to the person under investigation as a ground for the application of such a preventive measure as custody, while the stated risk is not provided for in the current CrPC of Ukraine. Korban v Ukraine App no 26744/16 (ECtHR, 04 July 2019) <http://hudoc.echr.coe.int/eng?i=001-194188> accessed 12 February 2021.

56 Tymoshenko v Ukraine App no 49872/11 (ECtHR, 30 April 2013) <http://hudoc.echr.coe.int/ eng?i=001-119382> accessed 12 February 2021. 
To this end they must examine all the facts arguing for or against the existence of a genuine requirement of public interest justifying, with due regard to the principle of the presumption of innocence, a departure from the rule of respect for individual liberty and set them out in their decisions ordering continued detention. ${ }^{57}$

Similar positions have been formulated in other decisions of the ECtHR. ${ }^{58}$

In the context of the study of the use of detention in court proceedings, it should be noted that the ECtHR drew attention to the lack of proper justification for the need to continue the preventive measure in the form of detention in numerous decisions of Ukraine while the CrPC of 1960 was in power (Todorov $v$ Ukraine, ${ }^{59}$ Yeloyev $v$ Ukraine, ${ }^{60}$ Vitruk $v$ Ukraine, ${ }^{61}$ Yurtaev $v$ $\left.U_{k r a i n} e^{62}\right)$. Despite the fact that the current CrPC of Ukraine has set a maximum period of detention only during the pre-trial investigation, the domestic approach to determining the length of detention of the accused during the trial is acceptable in international practice and meets international standards of freedom and personal integrity requiring the procedure for reviewing the legality of long-term application of this preventive measure, guaranteed by Part 3 of Art. 331 of the CrPC of Ukraine, which the court undertakes to periodically exercise ongoing judicial review of the appropriateness of further extension of the detention of the accused. In addition, the correlation with international standards is provided by the provisions of Part 2 of Art. 331 and Part 1 of Art. 196 of the CrPC of Ukraine, which establishes mandatory requirements for the validity of the court decision on the election or continuation of detention of the accused during the trial. It states the need to indicate the circumstances that note the existence of risks under Art. 177 of the CrPC of Ukraine circumstances that indicate the inadequacy of the application of more lenient measures to prevent the risks provided for in Art. 177 of the CrPC of Ukraine and provide evidence to substantiate these circumstances.

In conclusion, we can state that the current $\mathrm{CrPC}$ of Ukraine practically considers the legal conclusions of the ECtHR regarding the inconsistency of the procedure of application of a preventive measure in the form of detention that took place when the CrPC of Ukraine of 1960 was in power and are formulated in decisions against Ukraine, among others, in Kharchenko v Ukraine, Feldman v Ukraine, Hudz v Ukraine, Temchenko v Ukraine, and Baryshevsky v Ukraine. ${ }^{63}$

57 Tkachev $v$ Ukraine App no 39458/02 (ECtHR, 13 December 2007) <http://hudoc.echr.coe.int/ eng?i=001-83977> accessed 12 February 2021.

58 See, inter alia: Volosyuk v Ukraine App no 1291/03 (ECtHR, 12 March 2009) <http://hudoc.echr.coe. int/eng?i=001-76092> accessed 12 February 2021; Smirnova $v$ Russia App nos 46133/99 and 48183/99 (ECtHR, 24 July 2003) <http://hudoc.echr.coe.int/eng?i=001-61262> accessed 12 February 2021.

59 Todorov $v$ Ukraine App no 16717/05 (ECtHR, 12 January 2012) < http://hudoc.echr.coe.int/ eng?i=001-108578> accessed 12 February 2021.

60 Yeloyev $v$ Ukraine App no 17283/02 (ECtHR, 6 November 2008) <http://hudoc.echr.coe.int/ eng?i=001-89452 > accessed 12 February 2021.

61 Vitruk $v$ Ukraine App no 26127/03 (ECtHR, 16 September 2010) <http://hudoc.echr.coe.int/ eng?i=001-100385> accessed 12 February 2021.

62 Yurtayev $v$ Ukraine App no 11336/02 (ECtHR, 31 January 2006) <http://hudoc.echr.coe.int/ eng?i=001-72211 > accessed 12 February 2021.

63 Feldman $v$ Ukraine App nos 76556/01 and 38779/04 (ECrHR, 8 April 2010) <http://hudoc.echr.coe. int/eng?i=001-98112> accessed 12 February 2021; Kharchenko $v$ Ukraine App no 40107/02 (ECtHR, 10 February 2011) <http://hudoc.echr.coe.int/eng?i=001-103260> accessed 12 February 2021; Gudzv Ukraine App no 25032/11 (ECtHR, 22 October 2015) <https://www.bailii.org/eu/cases/ECHR/2015/929. html > accessed 12 February 2021; Temchenko v Ukraine App no 30579/10 (ECtHR, 16 July 2015) $<$ http://hudoc.echr.coe.int/eng?i=001-156073> accessed 12 February 2021; Baryshevskyy v Ukraine App no 71660/11 (ECtHR, 26 February 2015) <https://www.bailii.org/eu/cases/ECHR/2015/235.html> accessed 12 February 2021. 


\subsection{Problems of admissibility of evidence and ensuring the rights of individuals to review the materials of the pre-trial investigation}

The introduction of European standards for the protection of human rights and the expansion of the scope of such principles of criminal justice as adversarial proceedings and immediacy have led to significant changes of approaches to the standardisation of evidence and proof in the CrPC of Ukraine of 2012. Judgments of the ECtHR in Nechyporuk and Yonkalo $v$ Ukraine of 21 April 2011, Grigoriev v Ukraine of 15 May 2012, Yaremenko v Ukraine of 12 July 2008, Shabelnyk v Ukraine of 19 February 2009, Kaverzin v Ukraine of 15 May 2012, and others declared the violations of Art. 6 of the ECHR due to the use of evidence obtained in violation of Art. 3 of the ECHR. These decisions contributed to the fact that, for the first time in the legislation of Ukraine, the institution of admissibility of evidence, as well as provisions concerning the grounds and procedure for declaring factual data inadmissible for use in evidence, were enshrined in Chapter 4 'Evidence and Proof' and created the content of a separate legal institute. The CrPC established that evidence obtained as a result of a significant violation of human rights and freedoms guaranteed by the Constitution and laws of Ukraine, international treaties approved by the Verkhovna Rada of Ukraine, and any other evidence obtained as a result of a significant violation of human rights and freedoms are inadmissible (Art. 87 of the CrPC). It should be noted that the provisions of this article are quite popular in practice.

In Oleksiy Mykhaylovych Zakharkin v Ukraine (2010) ${ }^{64}$, the ECtHR stated that the CrPC victim did not duly address the issue of access to the case file by the victim or other interested persons at the pre-trial stages (para. 71). Due to this decision, a new article was added to the CrPC of Ukraine - Art. 221 'Familiarization with the materials of the pre-trial investigation before its completion', according to which the investigator, coroner, or prosecutor is obliged at the request of the defence, the victim, or a representative of the legal entity, to provide them with materials of the pre-trial investigation for review, except for materials on the application of security measures against persons involved in criminal proceedings, as well as those materials which at this stage of criminal proceedings could prejudice the pre-trial investigation. Moreover, the law forbade refusing to provide a publicly available document, the original of which is in the materials of the pre-trial investigation.

In addition, the CrPC established a system of guarantees for the opening of criminal proceedings for the side of the defence. In particular, in accordance with Art. 290 of the $\mathrm{CrPC}$, recognising the evidence gathered during the pre-trial investigation as sufficient to draw up an indictment, the prosecutor or investigator is obliged to notify the suspect and his/her defence counsel of the completion of the pre-trial investigation and provide access to pre-trial investigation materials. Moreover, the prosecutor or investigator is obliged to provide access to the materials of the pre-trial investigation and material evidence and the opportunity to copy or display any documents or copies thereof. Of course, the documents provided for review may lack information that will not be disclosed during the trial. The obligation to open the materials of the criminal proceedings will also be imposed on the defence, but only at the request of the prosecutor. Moreover, the defence party has the right not to provide the prosecutor with access to any materials that may be used by the prosecutor to confirm the guilt of the accused in committing a criminal offence. In such a model, the well-known principle of favor defensionis is implemented. In addition, the law provides for a procedural sanction in the form of inadmissibility of evidence for non-disclosure of materials by the parties to criminal proceedings (Part 12 of Art. 290 of the CrPC of Ukraine).

64 Oleksiy Mykhaylovych Zakharkin v Ukraine App no 1727/04 (ECtHR, 24 June 2010) para 71. <http:// hudoc.echr.coe.int/eng?i=001-99626> accessed 21 February 2021. 


\section{ECHR AS A LIVING INSTRUMENT AND ACT OF DIRECT ACTION}

We would also like to note the cases of direct application in the law enforcement practice of Ukraine of the decisions of the ECtHR, even when the legislator did not regulate certain provisions at the level of the CrPC. In particular, in Kulyk $v$ Ukraine of 2 February 2017 and Titarenko v Ukraine of 20 December 2012, ${ }^{65}$ the ECtHR criticised the detention of defendants in a metal 'cage' without reasonable justification, considering it a violation of Art. 3 of ECHR. In particular, the Court emphasised that the detention of a person in a metal 'cage' during a trial offends human dignity, as such treatment is objectively degrading and incompatible with standards of civilised conduct, which is a hallmark of a democratic society. The Court held that there was a violation of Art. 3 of the ECHR in respect to the conditions of the applicant's detention, including his placement in a metal cage in the courtroom. Based on the precedents of the ECtHR, the courts of Ukraine refused to equip the premises with metal cages and, at the request of the defence, clarified the issue of a real or specific security threat, which would require the suspect to be near the defence counsel glass cage.

Also, the approach of the ECtHR, which was formulated in the judgments of the ECtHR on Gorodnichev v Russia, Klyakhin $v$ Russia ${ }^{66}$ and Iglin $v$ Ukraine ${ }^{67}$ on the use of handcuffs during the trial is taken into account in Ukrainian courts to prevent violations connected with humiliation under Art. 3 ECHR. In particular, in these rights, the court pointed out the expediency of using handcuffs as special means in cases due to justified, reasonable requirements of public safety or the proper administration of justice.

\section{RESERVES FOR THE IMPROVEMENT OF NATIONAL LEGISLATION IN THE CONTEXT OF PROTECTION OF HUMAN RIGHTS AND FREEDOMS IN ACCORDANCE WITH THE LEGAL POSITIONS OF THE ECtHR}

Considering the impact of the case-law of the ECtHR on criminal procedure legislation, it should be noted that there are many cases of non-enforcement of ECtHR decisions or delays in enforcement. The following problems can be addressed in criminal procedural law. In particular, in the judgments of the ECtHR in Soldatenko $v$ Ukraine and Korneikova $v$ Ukraine, the ECtHR stated

The Court first ascertains whether the Convention itself complies with the national law and,
in particular, whether the general principles set out in it or derived from it, in particular
the general principle of legal certainty, which includes the "quality of the law", requiring
the law to comply with the principle of the rule of law, this idea permeates all articles of the
Convention. In this case, the "quality of the law" means that where a national law provides
for the possibility of deprivation of liberty, such a law must be sufficiently accessible, clearly
articulated and predictable in its application in order to eliminate any risk of arbitrariness.

$65 \quad$ KulykvUkraine, App no 30760/06(ECtHR,23June 2016)<http://hudoc.echr.coe.int/eng?i=001-163911> accessed 12 February 2021; Titarenko v Ukraine App no 31720/02 (ECtHR, 20 September 2012) <http:// hudoc.echr.coe.int/eng?i=001-113273> accessed 12 February 2021.

66 Gorodnitchev v Russia, App no 52058/99 (ECtHR, 24 May 2007) <http://hudoc.echr.coe.int/ eng?i=001-80611> accessed 12 February 2021; Klyakhin v Russia App no 46082/99 (ECtHR, 30 November 2004) <http://hudoc.echr.coe.int/eng?i=001-67584> accessed 12 February 2021.

67 Iglin v Ukraine App no 39908/05 (ECtHR, 12 January 2012) para 70-72 <http://hudoc.echr.coe.int/ eng?i=001-108506> accessed 12 February 2021.

68 See, inter alia: Soldatenko v Ukraine App no 2440/07 (ECtHR, 23 October 2008) <http://hudoc.echr.coe. int/eng?i=001-89161> accessed 12 February 2021; Korneykova $v$ Ukraine App no 39884/05 (ECtHR, 19 January 2012) <http://hudoc.echr.coe.int/eng?i=001-108654> accessed 12 February 2021. 
The current $\mathrm{CrPC}$ does not regulate the application of a precautionary measure during the pronouncement of a court decision. It concerns the detention of the accused on the basis of a sentence that has not entered into force. The current domestic practice when the court of first instance in the same document on its own initiative without discussion with the parties decides on the choice of a measure of restraint in the form of detention or its continuation with the wording 'until the sentence enters into force' contradicts the case-law of the ECtHR and confronts the principles of competition and dispositiveness.

Further, there is legal uncertainty regarding the victim's participation in the court proceedings to decide on the application of a precautionary measure. The ECtHR's position in Batsanina $v$ Russia concludes that the principles of equality and adversarial proceedings require a 'fair balance between the parties' and that each of them should be given a reasonable opportunity to present his/her position in conditions that do not put him/her in a less favourable position compared to his/her opponent. ${ }^{69}$ The normalisation of the victim's right to participate in deciding on the application of a precautionary measure will ensure the balance of interests of the parties and his/her right to judicial protection of his/her own interests, which should also be reflected in the CrPC of Ukraine.

There is also regulatory uncertainty regarding the duration of a preventive measure in the form of placement in a psychiatric institution in conditions that exclude its dangerous behaviour (given the fact that by its legal nature, this preventive measure is, in fact, equivalent to detention), and the lack of appeal of this decision. Thus, in particular, in the decision of the ECtHR in the case $M v$ Ukraine from 19 April 2012, it states that the decision on involuntary hospitalisation of a person in a psychiatric hospital must specify the maximum period after which these decisions are subject to official review in accordance with the law. ${ }^{70}$ With regard to the procedure for appealing a court decision on the placement of a person in a psychiatric institution, it should be noted that it is a standard recognised by the international community as a necessary guarantee to protect the rights of patients forcibly hospitalised in a psychiatric institution. ${ }^{71}$

\section{CONCLUSIONS}

Ukraine has proclaimed common European democratic values as a priority of its sociopolitical development and embarked on the path of deepening the influence of international law on national law and legal practice. This trend has necessitated the introduction of common European human rights standards, based on the ECHR and the case-law of the European Court of Human Rights as a living tool for its implementation. However, Ukraine's criminal procedure law did not meet international human rights standards, was outdated, and reflected the Soviet past, leading to numerous human rights violations due to the lack of effective judicial control mechanisms and proper human-centred legal procedures capable of securing the rights of both the suspect or the accused and the victim of the crime.

Based on Ukraine's ratification of the ECHR and the ECtHR's extensive case-law on Ukraine, the international legal nature of the Convention determined the need to comply with the

69 Batsanina $v$ Russia App No 8927/02 (ECtHR, 26 May 2009) <http://hudoc.echr.coe.int/eng?i=001-92667> accessed 12 February 2021.

$70 \quad$ M v Ukraine App no 2452/04 (ECtHR, 19 April 2012) <http://hudoc.echr.coe.int/eng?i=001-110515> accessed 12 February 2021.

71 Recommendation Rec (2004)10 of the Committee of Ministers to member states concerning the protection of the human rights and dignity of persons with mental disorder (Adopted by the Committee of Ministers on 22 September 2004 at the 896th meeting of the Ministers' Deputies) <https://search.coe. $\mathrm{int} / \mathrm{cm} /$ Pages/result_details.aspx?ObjectID=09000016805dc0c1 $>$ accessed 12 February 2021. 
Court's decisions in cases against it and subsequently accelerated the process of new criminal procedure. The adoption of the new CrPC of Ukraine (from 13 April 2012) was an important event for the state. The path to its preparation, which lasted several years, was not easy. It absorbed the most progressive international human rights standards, eliminated the shortcomings of outdated legislation identified by the ECtHR, and built on the ideology of the rule of law, the unconditional priority of universal values, such as freedom, personal integrity, and respect for human dignity. The general principles of criminal proceedings proclaim the rule of law, reasonable time, presumption of innocence, ensuring the right to defence, access to justice, adversarial proceedings, and others. The new Code significantly improves the legal regulation in the field of criminal justice, brings to it European values and principles, increases the efficiency and effectiveness of criminal proceedings, deformalises it, allows a fair balance between the interests of the state and the person prosecuted, and creates equal opportunities for parties to the prosecution and defence. The key role in the formation of a system of effective protection of individual rights in criminal proceedings, as shown by a systematic and meaningful analysis of ECtHR decisions, belongs to the Convention and the case-law of the ECtHR.

However, the practice of applying the new criminal procedure legislation, as well as the case-law of the ECtHR in Ukraine, demonstrates the impeccability of internal regulations, understanding of the main institutions of the criminal process by law enforcement, and, unfortunately, systemic problems. This provides the state with the task of improving the legislation without undue delay, eliminating the problems, and improving the mechanisms aimed at the immediate implementation of the decisions of the ECtHR issued against Ukraine.

\section{CONTRIBUTORS}

Prof. Oksana Kaplina is responsible for the supervision, including oversight and leadership responsibility for the research activity, planning, and execution, and writing, including review and editing, as well as the conceptualisation, formulation, and evolution of the overarching research goals and aims, design of the methodology, and writing the original draft.

Dr Tumanyants Anush conducts the research and maintains the investigation process, specifically data/evidence collection, and prepares the work, specifically the visualisation/data presentation.

Prof. Oksana Kaplina is a Head of the Department of Criminal Procedure, Correspondent Member of the National Academy of Legal Sciences, Honored Worker of Science and Technology of Ukraine, Member of the Scientific Advisory Board of the Supreme Court, Deputy Head of the Working Group on Reforming of Criminal Justice under the President of Ukraine, participant of the Erasmus+ Project Modernising Master's Training on Criminal Justice CRIMHUM

ORCID ID: 0000-0002-3654-673X o-kaplna@ukr.net

Dr Tumanyants Anush is an assoc. professor at the Department of Criminal Procedure at the Yaroslav Mudryi National Law University. ORCID ID: 0000-0001-6403-8436

\section{REFERENCES}

Grabenwarter C, 'The European Convention on Human Rights: Inherent Constitutional Tendencies and the Role of the European Court of Human Rights' in A von Bogdandy, P Sonnevend (eds), Constitutional Crisis in the European Constitutional Area, Theory, Law and Politics in Hungary and Romania (2015) 257-275; <https://eltelawjournal.hu/wpcontent/uploads/2014/10/7_Christoph_Grabenwarter.pdf> accessed 12 February 2021. Keller $\mathrm{H}$, Sweet A, 'Assessing the Impact of the ECHR on National Legal Systems' in A Europe of Rights: 
The Impact of the ECHR on National Legal Systems (Oxford University Press 2008) 677-712. <https:// digitalcommons.law.yale.edu/cgi/viewcontent.cgi?article=1087\&context=fss_papers> accessed 12 February 2021

Convention for the Protection of Human Rights and Fundamental Freedoms, 4 November 1950 <https://www.echr.coe.int/documents/convention_eng.pdf> accessed 12 February 2021

EA Alkema, 'The European Convention as a Constitution and Its Court as a Constitutional Court' in $\mathrm{P}$ Mahoney et al (eds), Protection des droits de l'homme: la perspective européenne: mélanges à la mémoire de Rolv Ryssdal (Cologne 2000) 41-65

Law of Ukraine'On the implementation of decisions and application of the case law of the European Court of Human Rights' [2006] Vidomosti of the Verkhovna Rada 18/123 <https://zakon.rada.gov. ua/laws/show/3477-15\#Text> accessed 12 February 2021

Law of Ukraine on Ratification of the Convention for the Protection of Human Rights and Fundamental Freedoms of 1950, First Protocol and Protocols No 2, 4, 7 and 11 to the Convention of the Verkhovna Rada of Ukraine (VVR) 1997 No 40, 263

De Salvia $\mathrm{M}$, 'Compendium de la CEDH: les Principes Directeurs de la Jurisprudence Relative à la Convention Européenne des Droits de l'Homme' in Jurisprudence 1960 à 2002 (2003) 865

Recommendation Rec (2004)10 of the Committee of Ministers to member states concerning the protection of the human rights and dignity of persons with mental disorder (Adopted by the Committee of Ministers on 22 September 2004 at the 896th meeting of the Ministers' Deputies) $<$ https://search.coe.int/cm/Pages/result_details.aspx?ObjectlD=09000016805dc0c1> accessed 12 February 2021.

Luzius W, 'Rethinking the European Court of Human Rights' in The European Court of Human Rights between Law and Politics (2011) 204-230 